ks. Marek Dzik

\title{
Spotkanie św. Pawła z przemienionym Jezusem pod Damaszkiem a przemienienie Jezusa na górze
}

Wszystkim czytelnikom Pisma Świętego doskonale znana jest scena spotkania św. Pawła z Chrystusem pod Damaszkiem. Równie znana jest scena przemienienia Jezusa na górze. Obie są tak wyraziste i sugestywne, że powstaje pytanie, czy pomiędzy tymi dwoma wydarzeniami istnieje jakiś związek? Odpowiedź na tak postawione pytanie jest oczywista: naturalnie tak - tym, co je łączy, jest fakt niezwykłego spotkania apostołów z Jezusem. Ale czy łączą je jakieś bliższe relacje, które mogą wskazywać na ściślejszą zależność obu tekstów? ${ }^{1}$ Niniejszy artykuł pragnie udowodnić, że taka zależność istnieje, i ukazać ją przede wszystkim pod względem powiązań literackich. W tym celu zostaną dokonane analizy porównawcze pomiędzy opisami przemienia Jezusa w Ewangeliach synoptycznych a opisami spotkania św. Pawła ze zmartwychwstałym Chrystusem pod Damaszkiem.

\section{Analizy ogólne}

Przystępując do porównania opisu spotkania trzech apostołów z przemienionym Jezusem oraz opisu spotkania Pawła z uwielbionym Zbawicielem, trzeba mieć świadomość, że zarówno te zawarte w Ewangeliach synoptycznych, jak i te w Dziejach różnią się pomiędzy sobą. Wydaje się zatem, że najpierw należy przyjrzeć się każdemu z wydarzeń z osobna, następnie zestawić je, szukając wspólnych elementów. Wyciągnięte wnioski będą stanowily podstawę do dalszych analiz.

${ }^{1}$ Sugestie takie, lecz natury ogólnej, są znajdywane u G. Lohfinka czy K. Haackera. Koncentrują się oni przede wszystkim na pewnych stałych elementach chrystofanii w nawiązaniu do Starego Testamentu - zob. G. Lohfink, Paulus vor Damaskus, Stuttgart 1965, s. 22-79 (Stuttgarter Bibelstudien, 4); K. Haacker, Paulus. Der Werdegang eines Apostels, Stuttgart 1997, s. 105-113 (Stuttgarter Bibelstudien, 171). 


\section{PRZEMIENIENIE JEZUSA NA GÓRZE}

W Ewangeliach synoptycznych opis przemienia Jezusa pojawia się w następujących tekstach: Mt 17, 1-8; Mk 9, 2-8; Łk 9, 28-37a². Każdy $\mathrm{z}$ autorów uznał ten fakt za tak ważny, że zamieścił go w swojej księdze. To, że ich teksty są do siebie podobne, świadczy o korzystaniu z tego samego źródła ${ }^{3}$. Każdy posiada jednakże swoją specyfikę wynikającą zapewne między innymi z teologii, którą prezentuje $e^{4}$.

\section{Podobieństwa}

Jeśli porównać rzeczone fragmenty, to do elementów wspólnych zaliczają się:

- bohaterowie wydarzenia: Bóg, Jezus, Piotr (jest najważniejszy, ponieważ zawsze wymieniany jest na pierwszym miejscu i tylko on przemawia) i pozostali uczniowie: Jakub i Jan (na podstawie Łk 9, 32 można odnieść wrażenie, że pełnią rolę świadków Piotra ${ }^{5}$ ) oraz Mojżesz i Eliasz (pełnią rolę świadków Jezusa);

- przebieg wydarzenia: można je podzielić na trzy części: wstęp, rozwinięcie i zakończenie. We wstępie jest mowa o udaniu się Jezusa wraz z uczniami na górę. Akcja jest dynamiczna, Jezus i apostołowie są

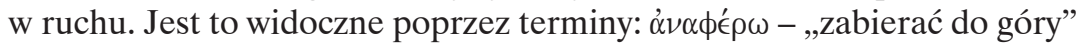

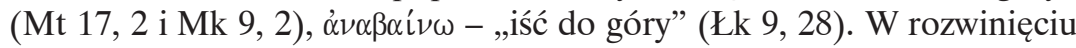
zaprezentowane są przemienienie Jezusa, reakcja Piotra i jego towarzyszy - propozycja postawienia trzech namiotów, głos z nieba (Boga) objawiający godność Jezusa, pojawiający się obłok, pojawienie się Mojżesza i Eliasza, zachowanie tajemnicy. Scena jest w tym kluczowym momencie bardziej statyczna, choć można także mówić o elementach dynamicznych. U Ma-

${ }^{2} \mathrm{Z}$ uwagi na formę artykułu zostanie ograniczony w maksymalnym stopniu problem delimitacji poszczególnych tekstów. Ich rozmiar w przypadku Mateusza i Marka jest powszechnie przyjmowany. Co się tyczy Łukasza, to zazwyczaj uważa się, że perykopa ta kończy się w w. 36. Jeśli jednak wziąć pod uwagę paralelne teksty, to należy przyjąć, że jej zakończenie znajduje się w w. 37a. W przeciwnym wypadku można odnieść wrażenie, że opowiadanie to jest niedokończone. W w. 37a, podobnie jak u Mt 17, 9 i Mk 9, 9, jest bowiem mowa o zejściu z góry. Z drugiej strony należy zgodzić się, że werset ten stanowi równocześnie wstęp do następnego fragmentu. Dlatego może być uznany za łącznik z wydarzeniem uzdrowienia epileptyka $(9,37 b-43)$.

${ }^{3}$ Pominięto dyskusje na temat hipotez dotyczących liczby źródeł, które znajdują się u podstaw Ewangelii synoptycznych - szerzej na ten temat zob. np. M. Bednarz, Ewangelie synoptyczne, Tarnów 1996³ , s. 19-23 (Academica, 4).

${ }^{4}$ Szczegółowe analizy na ten temat zob. M. Kokot, Myśl teologiczna przedsynoptycznych i synoptycznych przekazów o przemienieniu Pańskim, „Seminare. Poszukiwania naukowopastoralne" 4 (1979), s. 19-27.

${ }^{5}$ Por. F. Gryglewicz, Ewangelia wedtug św. Łukasza. Wstęp. Przekład z oryginału. Komentarz, Poznań-Warszawa 1974, s. 200. 


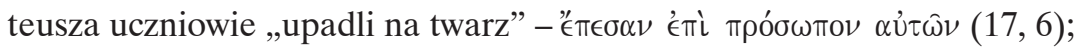
u Łukasza dynamizm dotyczy Mojżesza i Eliasza: „gdy oni odchodzili” -

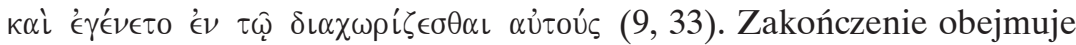
zejście z góry. Ruch jest oddany w opisach Mateusza i Marka terminem

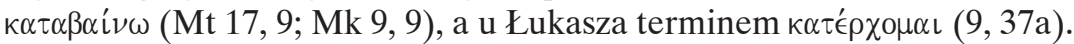
Oba czasowniki znaczą „schodzić”.

\section{Różnice}

Gdy dokładnie przyjrzeć się trzem opisom, widoczne są dość znaczne różnice. Jest ich dużo, znajdują są niemalże w każdym elemencie wydarzenia, zwrócimy więc uwagę tylko na najważniejsze. Zazwyczaj dotyczą one terminologii, choć niekiedy także kolejności i przebiegu zdarzeń.

Opowiadanie rozpoczyna się od określenia czasu. Mateusz czyni to na-

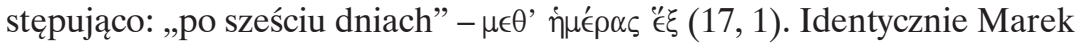
$(9,2)$. Łukasz natomiast używa innego określenia czasu, poprzedzonego zwrotem, którego nie stosują pozostali synoptycy: „W jakieś osiem dni po

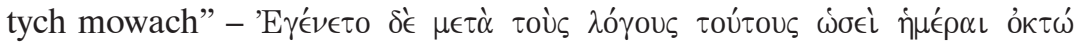
$(9,28)$. Następnie jest mowa o tym, że Jezus wziął ze sobą Piotra, Jakuba i Jana. Piotr zawsze występuje na pierwszym miejscu. Mateusz $(17,1)$ i Marek $(9,2)$ po Piotrze wymieniają Jakuba, jednak Łukasz zmienia tę kolejność, bo na drugim miejscu po Piotrze stawia Jana $(9,28)$. Na określenie wyjścia

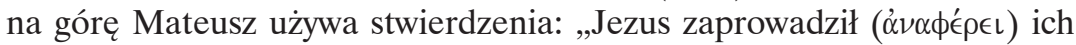
na górę wysoką osobno" $(17,1)$, Marek wyraża się niemalże identycznie, dodając określenie $\mu$ óvous - „samych” (9, 2), a Łukasz mówi, że Jezus „wy-

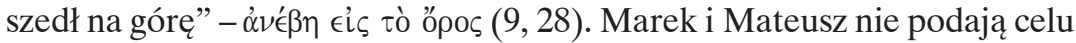
wyprawy, natomiast Łukasz podaje, że było nim pragnienie modlitwy Jezusa

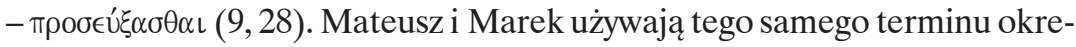

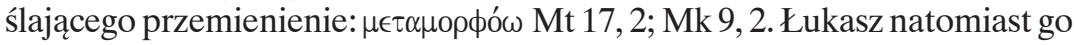
nie stosuje. Także opisy samego przemienienia Jezusa różnią się od siebie. Mateusz zauważa, że „Jego twarz zajaśniała jak słońce, odzienie zaś stało się białe jak światło” $(17,2)$. Marek mówi tylko o „odzieniu”, które „stało się lśniąco białe” (9,3). Łukasz stwierdza, że ,wygląd Jego twarzy się odmienił, a Jego odzienie stało się lśniąco białe" $(9,29)$. Wraz z Jezusem ukazują się Mojżesz i Eliasz, którzy z Nim rozmawiają. Łukasz opóźnia jednak moment spotkania trzech apostołów z przemienionym Jezusem, wtrącając wzmiankę o ich śnie z powodu zmęczenia $(9,32)$. Być może w ten sposób nawiązuje do sytuacji z Ogrojca (22, 39-45). Przemienieniu Jezusa i pojawieniu się Mojżesza oraz Eliasza towarzyszy obłok. Jego opis za każdym razem jest

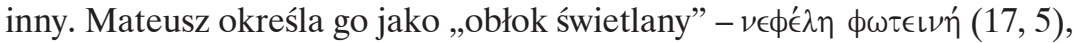
Marek $(9,7)$ i Łukasz $(9,34-35)$ nazywają go po prostu „obłokiem”- $\nu \in \phi \in ́ \lambda \eta$. 


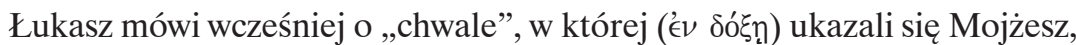
Eliasz i Jezus (9, 30-32). Tylko trzeci ewangelista podaje temat rozmowy Mojżesza i Eliasza z Jezusem - „Jego odejście w Jerozolimie” (9, 31). Reakcją Piotra na zaistniałe wydarzenia jest zwrócenie się do Jezusa z propozycją postawienia trzech namiotów. Czyniąc to, używa według Mateusza zwrotu

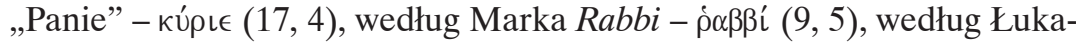

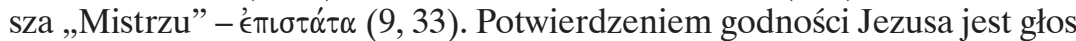
z nieba. Zdaniem Mateusza brzmi on w następujący sposób: „to jest mój Syn umiłowany, w którym mam upodobanie” $(17,5)$, zdaniem Marka: „to jest mój Syn umiłowany, Jego słuchajcie” $(9,7)$, a zdaniem Łukasza: „to jest mój Syn wybrany, Jego słuchajcie" $(9,35)$. Reakcją uczniów na głos z nieba w Ewangelii Mateusza jest upadnięcie na twarz i strach $(17,6)$, w Ewangelii Marka właściwie nie ma opisu ich reakcji, a w Ewangelii Łukasza jest mowa o strachu, który jednakże pojawia się wcześniej, to znaczy w trakcie składania Jezusowi propozycji przez Piotra dotyczącej postawienia trzech namiotów $(9,34)$. Wracając z góry, Jezus w Ewangelii Mateusza i Marka przykazał uczniom zachować milczenie: „aż Syn Człowieczy zmartwychwstanie” (Mt 17, 9), „zanim Syn Człowieczy nie powstanie z martwych” (Mk 9, 9). W Ewangelii Łuksza mimo braku zakazu milczenia jest mowa o takim zachowaniu uczniów $(9,36)$.

Okazuje się zatem, że wiele szczegółów historii przemienienia Jezusa w wersjach poszczególnych ewangelistów różni się między sobą. Trzy opisy nie wykluczają się jednak, lecz są względem siebie komplementarne, tworząc zasadniczo spójny obraz tego wydarzenia.

\section{SPOTKANIE ŚW. PAWŁA Z JEZUSEM}

Opis spotkania Pawła z Jezusem pojawia się trzykrotnie: Dz 9, 3-9; $22,6-11 ; 26,12-18^{6}$. Tak jak w przypadku opisu przemienienia Jezusa wymagają one wnikliwej analizy porównawczej.

${ }^{6}$ Podobnie jak w poprzednim przypadku, choć z większą siłą, pojawia się problem delimitacji tekstów. Wydaje się, że do celów porównawczych z opisem przemienienia Jezusa należy wziąć pod uwagę tylko samo wydarzenie spotkania Pawła z Jezusem pod Damaszkiem. Jeśli chodzi o pierwszy opis nawrócenia Pawła, to jego główna część obejmuje wersety 3-9 - por. H. Langkammer, Apostoł Paweł. Od nawrócenia aż po Rzym, Lublin 2002, s. 65 (Jak rozumieć Pismo Święte, 12); J. Jervell, Die Apostelgeschichte, Göttingen 1998, s. 280 (Kritisch-exegetischer Kommentar über das Neue Testament, 3); R. Pesch, Die Apostelgeschichte (Apg 1-12), Zürich $1995^{2}$, s. 305 (Evangelisch-katholischer Kommentar zum Neuen Testament, 5.1). Za jądro drugiego opisu nawrócenia Pawła należy uznać Dz 22, 6-11. Pośrednio wskazuje na to komentarz do tekstu Dz 22, 1-21 autorstwa R. Pescha, który oddzielnie analizuje fragment 22, 6-11 - por. tenże, Die Apostelgeschichte (Apg 13-28), Zürich 1986, s. 234 (Evangelischkatholischer Kommentar zum Neuen Testament, 5.2). Trzeci opis nawrócenia Pawła przede wszystkim dotyczy Dz 26, 12-18. Sugeruje to R. Pesch, według którego tekst Dz 26, 4-23 należy podzielić na 3 części: 26, 4-11. 12-18. 19-23 - por. tamże, s. 274. 


\section{Podobieństwa}

Porównując wyżej wymienione perykopy, zauważa się następujące elementy wspólne:

- bohaterami wydarzenia są: Jezus (światłość z nieba, głos), Paweł, jego towarzysze;

- przebieg wydarzenia można podzielić na trzy części: wstęp, rozwinięcie, zakończenie.

Wstęp obejmuje podanie celu wyprawy Pawła, którym był Damaszek.

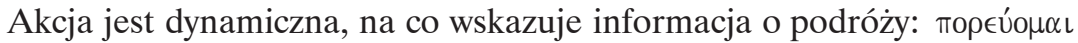
- „podążać” (Dz 9, 3; 22, 6; 26, 12). W rozwinięciu jest mowa o światłości z nieba. Wraz ze światłością pojawia się tajemniczy głos, który stawia Pawłowi pytanie dotyczące powodów prześladowania Jezusa: „Szawle, Szawle, dlaczego mnie prześladujesz?". Paweł odpowiada pytaniem o godność pytającego: „Kto jesteś, Panie?”. Słyszy, że jest nim prześladowany Jezus. Akcja ulega spowolnieniu, choć pojawiają się także elementy dynamiczne. Pierwszym jest upadek Pawła: Dz 9, 4; 22, 7; 26, 14; drugim - polecenie, by powstał: Dz 9, 6; 22, 10; 26, 16. Polecenie powstania można określić jako ostatni wspólny dynamiczny motyw kończący jądro opowiadania. Teksty Dz 9, 8 i 22, 11 należy uznać za zakończenie. Ich odpowiednik w trzecim opisie różni się od pozostałych, o czym będzie mowa w kolejnym punkcie.

\section{Różnice}

Każde z trzech opowiadań ma swoją specyfikę, co powoduje, że pojawiają się między nimi różnice. Podobnie jak w przypadku przemienienia jest ich dużo, tak że skupimy się tylko na najważniejszych.

Rozbieżności wynikają przede wszystkim stąd, że poszczególne teksty mają różnych narratorów: Dz 9, 3-9 to relacja redaktora Dziejów Apostolskich, Dz 22, 6-11 i Dz 26, 12-18 to świadectwa samego Pawła. Różnice są widoczne w używanej terminologii oraz kolejności i przebiegu zdarzeń. Paweł, zbliżając się w swojej podróży do Damaszku, doświadczył światłości z nieba. Dz 9, 3 tak to opisują: „olśniła go nagle światłość z nieba”. W Dz 22, 6 pada stwierdzenie: „około południa otoczyła mnie wielka jasność z nieba”. W Dz 26, 13 czytamy: ,ujrzałem [...] światło z nieba, jaśniejsze od słońca, które ogarnęło mnie i moich towarzyszy podróży”. Po usłyszeniu głosu z nieba następuje upadek Pawła. W Dz 9, 4 i 22, 7 dotyczy on tylko samego apostoła i jest opisany za pomocą tego samego terminu $\pi i \pi \tau \omega-$ „upadać”. W Dz 26, 14 dotyczy Pawła oraz jego towarzyszy i jest opisany jako $\kappa \alpha \tau \alpha \pi i \pi \tau \omega$ - „runąć”. Na dodatek pada tu stwierdzenie: „Trudno ci wierzgać przeciwko ościeniowi”. Po pytaniu Pawła, z kim ma do czynienia, następuje odpowiedź. W Dz 9, 5 i 26, 15 jest ona identyczna: „Ja jestem 
Jezus, którego ty prześladujesz”. W Dz 22, 8 brzmi ona nieco inaczej: „Ja jestem Jezus Nazarejczyk, którego ty prześladujesz". Następnie pojawiają się coraz większe różnice dotyczące nie tylko terminologii, ale także przebiegu zdarzeń. Według pierwszego opowiadania Jezus poleca Pawłowi powstać i udać się do miasta, gdzie dowie się, co dalej czynić (Dz 9, 6). Ludzie, którzy mu towarzyszyli w drodze, „oniemieli ze zdumienia, słyszeli bowiem głos, lecz nie widzieli nikogo" (Dz 9, 7). Paweł po powstaniu nic nie widzi. Zatem towarzysze wprowadzają go do Damaszku, gdzie przez trzy dni nic nie widział, nic nie jadł, ani nic nie pił (Dz 9, 8-9). W drugim z omawianych fragmentów Dziejów Apostolskich najpierw jest mowa o towarzyszach Jezusa, którzy „widzieli światło, ale [...] nie słyszeli głosu” (Dz 22, 9), potem Paweł pyta, co ma czynić (Dz 22, 10a), a dopiero na końcu dowiaduje się, że ma się udać do Damaszku (Dz 9, 10b), by tam zostać poinformowanym, jakie będzie jego zadanie. Do Damaszku zostaje wprowadzony przez towarzyszy $(\mathrm{Dz} 9,11)$. Według trzeciego opisu Jezus poleca Pawłowi powstać i wyjawia mu cel swego ukazania się: „ukazałem się tobie po to, aby ustanowić cię sługą i świadkiem tego, co zobaczyłeś, i tego, co ci objawię" (Dz 26, 16). Zapewnia go też o ochronie przed ludem i poganami (Dz 26, 17) oraz jeszcze raz podaje cel jego nawrócenia: „abyś otworzył im oczy i odwrócił od ciemności do światła, od władzy szatana do Boga. Aby przez wiarę we Mnie otrzymali odpuszczenie grzechów i dziedzictwo ze świętymi” (Dz 26, 18). Brak jest ostatniego wspólnego elementu ruchu w postaci udania się do Damaszku. Stwierdzenie o dokończeniu podróży do Damaszku znajduje się co prawda w Dz 9, 8 i 22, 11, lecz brak jest go w Dz 26, 12-18.

Widać zatem, że różnice, jakkolwiek niekiedy dość liczne, dotyczą drugorzędnych szczegółów, które nie zaburzają spójności opowiadania.

\section{PODOBIEŃSTWA I RÓŻNICE POMIĘDZY OPISEM PRZEMIENIENIA} JEZUSA NA GÓRZE A OPISEM SPOTKANIA ŚW. PAWŁA Z JEZUSEM

Dotychczasowe analizy wykazały, że opisy wydarzeń, zarówno przemienienia Jezusa na górze, jak i spotkania Pawła z przemienionym Jezusem, oprócz istotnych podobieństw zawierają dość znaczne modyfikacje. Interesującą więc rzeczą będzie zestawienie stałych elementów obydwu opowiadań ze sobą po to, aby odkryć istniejące pomiędzy nimi podobieństwa i różnice.

\section{Podobieństwa}

Zestawienie tak różnych na pierwszy rzut oka wydarzeń wydaje się ryzykowne, pozwala jednak na uchwycenie zaskakujących zależności między opisami spotkań Zbawiciela z wybranymi uczniami: Piotrem i Pawłem. 
Najłatwiejsze do uchwycenia jest podobieństwo w doborze bohaterów. W przypadku przemienienia są nimi: przemieniony Jezus, Bóg Ojciec (głos Boży), Piotr (który jest ważniejszy od jego dwóch towarzyszy - Jakuba i Jana) oraz Mojżesz i Eliasz (którzy pełnią rolę świadków Jezusa). W przypadku spotkania Pawła z Jezusem są nimi: uwielbiony Jezus (głos Jezusa), Paweł i towarzysze (pełnią rolę świadków). Stałym elementem obu scen jest obecność pary bohaterów - przemienionego Jezusa i apostoła. Za każdym razem pojawiają się też świadkowie tych wydarzeń.

Inne podobieństwo związane jest $\mathrm{z}$ dynamizmem i przebiegiem akcji. W przypadku przemienienia wygląda ona następująco: wstęp - wyjście Jezusa z uczniami na górę (ruch); rozwinięcie - przemienienie Jezusa (światłość), reakcja Piotra (i pozostałych uczniów) na wydarzenie, prezentacja Jezusa przez Boga (głos Boga); zakończenie - zejście z góry (ruch). W przypadku spotkania Pawła z uwielbionym Jezusem: wstęp - podróż do Damaszku (ruch); rozwinięcie - spotkanie z uwielbionym Jezusem (światłość, głos Jezusa), reakcja Pawła (i towarzyszy) na wydarzenie, autoprezentacja Jezusa; zakończenie - w przypadku Dz 9, 8 i Dz 22, 11 wejście do Damaszku (ruch).

Z powyższego zestawienia wynika, że zarówno najważniejsze elementy obydwu opowiadań, jak i ich przebieg są zbliżone.

\section{Różnice}

Obok wymienionych podobieństw w obu opowiadaniach są widoczne dość znaczne różnice. W Ewangeliach synoptycznych akcent pada na osobę Jezusa, a w Dziejach Apostolskich na Pawła. Towarzyszami Piotra są znani apostołowie Jakub i Jan, towarzyszami Pawła jacyś anonimowi ludzie. Piotr i jego towarzysze od początku są świadomi, że mają do czynienia z Jezusem, otrzymują polecenie słuchania Go. Paweł i jego towarzysze początkowo nie wiedzą, z kim się spotykają, zaś Paweł dopiero ma się dowiedzieć, jakie będzie jego zadanie. Konsekwencją przemienienia jest to, że trzej apostołowie otrzymują nakaz milczenia, zaś Paweł po swoim spotkaniu z Jezusem stracił wzrok. W opowiadaniu o przemienieniu na górze pojawia się Bóg w postaci głosu, w opowiadaniu o spotkaniu pod Damaszkiem brak jest Boga Ojca, a także Mojżesza i Eliasza. W pierwszej scenie Jezus widoczny jest w postaci cielesnej, choć ubóstwionej, w drugiej pojawia się jako „światłość z nieba”.

\section{Podobieństwo czy różnica?}

Porównując oba wydarzenia, warto przyjrzeć się miejscom, w których się rozegrały. Na pierwszy rzut oka wydaje się, że nie mają ze sobą nic 
wspólnego, ponieważ w pierwszym wypadku mamy do czynienia z górą, w drugim z drogą do Damaszku. Bliższa analiza określenia „góra” nasuwa jednak ciekawe wnioski.

Niektórzy egzegeci, opisując ją, koncentrują się na jej prawdopodobnej lokalizacji geograficznej ${ }^{7}$. Podawane są różne hipotezy, gdyby jednak przyjąć, że była nią góra Hermon, okaże się, że leży ona zaskakująco blisko Damaszku ${ }^{8}$, a więc zarówno przemienienie Jezusa, jak i spotkanie $\mathrm{z}$ uwielbionym Jezusem miałoby miejsce w tej samej pogańskiej okolicy.

Inni egzegeci próbują odczytać określenie „góra” w sposób symboliczny. Zwraca tu uwagę artykuł K.P. Fischera, który przekonuje, że góra objawienia, leżąca prawdopodobnie na granicy ze światem pogańskim, stanowiła pomost umożliwiający głoszenie ewangelii wszystkim narodom. Jest to przede wszystkim widoczne u Mateusza ${ }^{9}$. Takie rozumienie góry harmonizuje również z miejscem spotkania Pawła z uwielbionym Jezusem pod Damaszkiem, ponieważ w obu przypadkach była to przestrzeń działalności wczesnego Kościoła, który niósł ewangelię poganom. Zatem można postawić tezę, że miejsca obu spotkań więcej łączy, niż dzieli.

Przemienienie Jezusa na górze a spotkanie św.

Pawła z Jezusem - analizy szczegółowe

$\mathrm{Na}$ kanwie dotychczasowych ustaleń nastąpi teraz bezpośrednie porównanie perykop ukazujących przemienienie Jezusa z perykopami ukazującymi spotkanie Pawła z uwielbionym Jezusem, mające na celu zestawienie pojawiających się w nich podobieństw dotyczących najważniejszych elementów danego opowiadania od strony terminologicznej. Elementy, którymi różnią się poszczególne teksty, zostały już wyliczone, tym razem można je więc będzie pominąć.

MK 9, 2-8 I DZ 9, 3-9

Wspólne ważne terminy i pojęcia to:

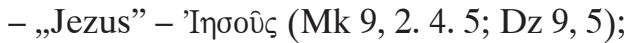

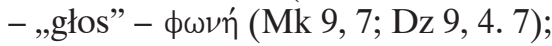

${ }^{7}$ Por. np. A. Paciorek, Ewangelia wedtug Świętego Mateusza. Rozdziały 14-28. Wstęp, przekład z oryginatu, komentarz, t. 2, Częstochowa 2008, s. 162 (Podręczny komentarz biblijny. Nowy Testament, 1.2); E. Firlej, Przemienienie Jezusa wedtug Synoptyków, „Novum” 20 (1977), nr 4-5, s. 86-87; F. Gryglewicz, Ewangelia wedtug św. Łukasza, dz. cyt., s. 197.

${ }^{8} \mathrm{Na}$ temat lokalizacji Hermonu zob. F. Rienecker, G. Maier, Hermon, [w:] Leksykon biblijny, Warszawa 2001, s. 273.

${ }^{9}$ Szerzej zob. K. P. Fischer, Der Berg in den Evangelien Zeichen für die Völker, „Biblische Notizen" 99 (1999), s. 49-54. 
- „mówić” - $\lambda^{\prime} \gamma^{\prime} \omega$ (Mk 9, 5: Piotr mówi do Jezusa; Dz 9, 4: głos mówi do Pawła; Dz 9, 5: Paweł mówi do Jezusa);

- „słyszeć” - ג̇кoúw (Mk 9, 7: nakaz słuchania Syna; Dz 9, 4: Paweł słyszy głos; Dz 9, 7: ludzie słyszą głos);

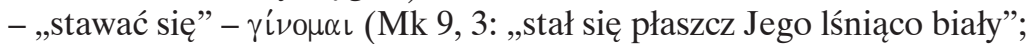
Mk 9, 6: „stali się przestraszeni”; Mk 9, 7: „stał się obłok”, „stał się głos”; Dz 9, 3: „stało się, gdy się zbliżał”);

- „widzieć” - ópów (Mk 9, 4: dotyczy widzenia Mojżesza i Eliasza; Mk 9, 8: dotyczy widzenia ziemskiego Jezusa). W Dz 9, 7 występuje termin $\theta \epsilon \omega \rho \epsilon \in \omega$ (dotyczy braku widzenia kogokolwiek przez towarzyszy Pawła); a w Dz 9, 8. 9 - $\beta \lambda \epsilon ́ \pi \omega$ (dotyczy braku widzenia przez Pawła). Termin ópów w Dziejach Apostolskich pojawił się też później, gdy Paweł w wizji ujrzał Ananiasza $(9,12)$, oraz gdy Ananiasz powiedział Pawłowi, że Jezus, którego on widzi, przysłał go do niego $(9,17)$;

- „rozmawiać” - $\sigma u \lambda \lambda \alpha \lambda \lambda^{\epsilon} \omega($ Mk 9, 4: Mojżesz i Eliasz rozmawiają z Jezusem). W Dz 9, 6 występuje $\lambda \alpha \lambda \lambda^{\epsilon} \omega$ (Pawłowi powiedzą w mieście, co ma czynić);

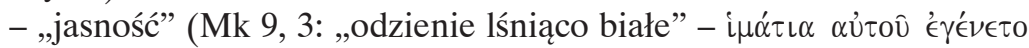

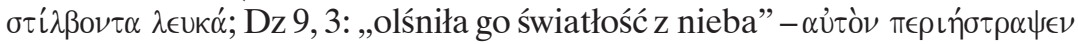

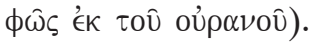

Podobieństwo terminologiczne należy ocenić jako dość duże. Wspólne terminy wydają się być istotne dla obu wydarzeń. Brak identycznych terminów dotyczących rozmawiania i widzenia.

MK 9, 2-8 I DZ 22, 6-11

Wspólne ważne terminy i pojęcia to:

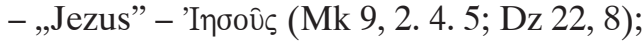

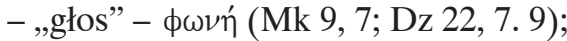

- „mówić” - $\lambda^{\prime} \hat{\gamma} \omega$ (Mk 9, 5: Piotr mówi do Jezusa; Dz 22, 7: głos mówi do Pawła; Dz 22, 8: Paweł mówi do Jezusa; Dz 22, 10: Paweł mówi do Jezusa, Jezus mówi do Pawła);

- „słyszeć” - ג̇кoúw (Mk 9, 7: nakaz słuchania Syna; Dz 22, 7: Paweł słyszy głos; Dz 22, 9: towarzysze Pawła nie słyszą głosu);

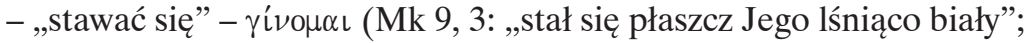
Mk 9, 6: „stali przestraszeni”; Mk 9, 7: „stał się obłok”, „stał się głos”; Dz 22, 6: „stało się, gdy się zbliżałem”);

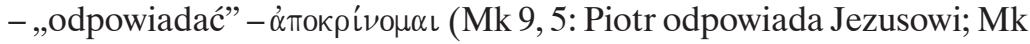
9, 6: Piotr nie wie, co odpowiedzieć; Dz 22, 8: Paweł odpowiada głosowi);

- „widzieć” - ópów (Mk 9, 4: dotyczy widzenia Mojżesza i Eliasza; Mk 9, 8: dotyczy widzenia ziemskiego Jezusa). W Dz 22, 9 ópów jest zastąpione 


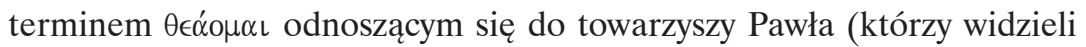
światło), a w Dz 22, 11 przez '́ $\mu \beta \lambda \epsilon^{\prime} \pi \omega$ odnoszącym się do braku widzenia przez Pawła. Termin ópów pojawił się też w Dz później, gdy Ananiasz przemawiał do Pawła, informując go, dlaczego został powołany $(22,14.18)$;

- „rozmawiać” - $\sigma u \lambda \lambda \alpha \lambda \epsilon ́ \omega($ Mk 9, 4: Mojżesz i Eliasz rozmawiają z Jezusem). W Dz 22, 9. 10 występuje $\lambda \alpha \lambda \lambda^{\epsilon} \omega$ : towarzysze Pawła nie słyszą głosu mówiącego do niego; w mieście powiedzą Pawłowi, co ma czynić;

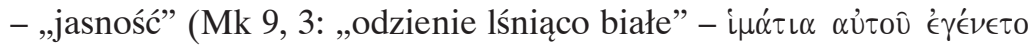

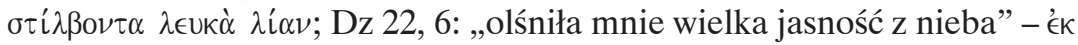

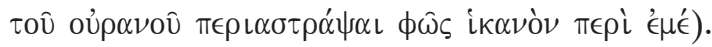

Podobieństwo terminologiczne należy ocenić jako dość duże. Wydaje się, że wspólne terminy są istotne dla obu wydarzeń. Brak identycznych terminów dotyczących rozmawiania i widzenia.

MK 9, 2-8 I DZ 26, 12-18

Wspólne ważne terminy i pojęcia to:

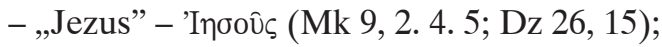

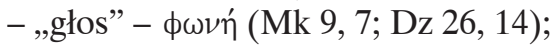

- „mówić” - $\lambda$ '́ $\gamma \omega$ (Mk 9, 5: Piotr mówi do Jezusa; Dz 26, 14: głos mówi do Pawła; Dz 26, 15: Paweł mówi do uwielbionego Jezusa, Jezus mówi do Pawła);

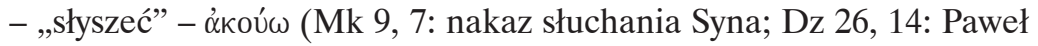
słyszy głos);

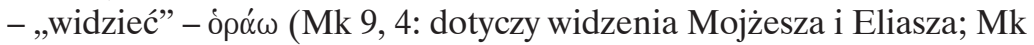
9, 8: dotyczy widzenia ziemskiego Jezusa; Dz 26, 13: Paweł ujrzał jasność z nieba; Dz 26, 16: dwa razy dotyczy widzenia uwielbionego Jezusa, raz przyszłego objawienia Pawłowi przez Jezusa czegoś nowego);

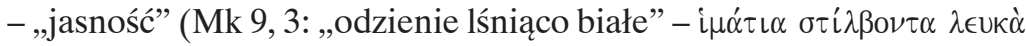
$\lambda i \alpha \nu ;$ Dz 26, 13: „jaśniejsze od słońca światło z nieba, które oświeciło mnie

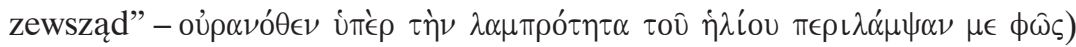

Podobieństwo terminologiczne należy ocenić jako dość duże. Wspólne terminy wydają się być istotne dla obu wydarzeń. Co się tyczy widzenia, pomimo iż w obu tekstach pojawia się ten sam termin ópó $\omega$, to jednak u Marka nie odnosi się on do widzenia przemienionego Jezusa.

MT 17, 1-8 I DZ 9, 3-9

Wspólne ważne terminy i pojęcia to:

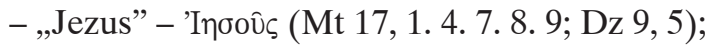

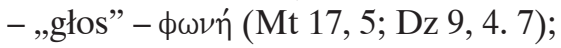


- „mówić” - $\lambda \lambda^{\prime} \gamma \omega$ (Mt 17, 4: Piotr mówi do Jezusa; Mt 17, 5: głos z obłoku mówi do apostołów; Mt 17, 7: Jezus mówi do apostołów; Dz 9, 4: głos mówi do Pawła; Dz 9, 5: Paweł mówi do Jezusa);

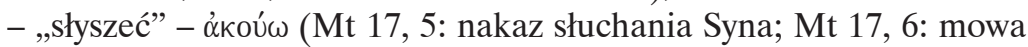
o usłyszeniu przez uczniów głosu; Dz 9, 4: Paweł słyszy głos; Dz 9, 7: ludzie słyszą głos);

- „Pan”- kúpıьs (Mt 17, 4; Dz 9, 5);

- „Światło” - $\phi \omega \hat{~}($ Mt 17, 2; Dz 9, 3);

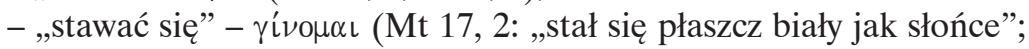
Dz 9, 3: „stało się, gdy się zbliżał”);

- „rozmawiać” - $\lambda \alpha \lambda \epsilon \in \omega$ (Mt 17, 5: „gdy Piotr mówił, osłonił ich obłok świetlany"10; Dz 9, 6: w mieście powiedzą Pawłowi, co ma czynić);

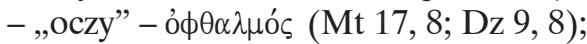

- „widzieć” - ópów (Mt 17, 3: dotyczy widzenia Mojżesza i Eliasza; Mt 17, 8: dotyczy widzenia ziemskiego Jezusa. W Dz 9, 7 występuje termin

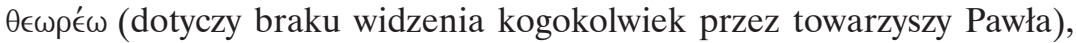
a w Dz 9, 8. 9 - $\beta \lambda \epsilon ́ \pi \omega$ (dotyczy braku widzenia przez Pawła);

- „jasność” (Mt 17, 2: „twarz Jego zajaśniała jak słońce, odzienie zaś

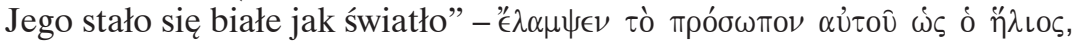

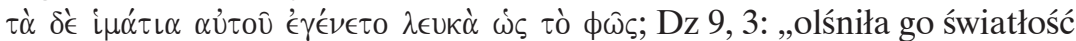

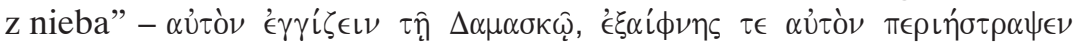

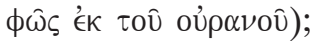

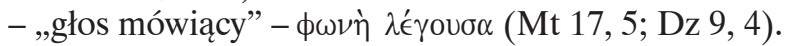

Podobieństwo terminologiczne należy ocenić jako bardzo duże. Wspólne terminy wydają się być istotne dla obu wydarzeń. Brak wspólnego terminu dotyczącego widzenia.

MT 17, 1-8 I DZ 22, 6-11

Wspólne ważne terminy i pojęcia to:

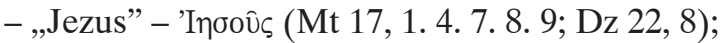

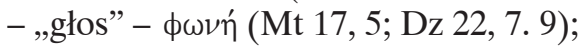

- „mówić” - $\lambda^{\prime} \in \omega \omega$ (Mt 17, 4: Piotr mówi do Jezusa; Mt 17, 5: głos z obłoku mówi do apostołów; Mt 17, 7: Jezus mówi do apostołów; Dz 22, 7: głos mówi do Pawła; Dz 22, 8: Jezus mówi do Pawła; Dz 22, 10: Paweł mówi do Jezusa, Jezus mówi do Pawła);

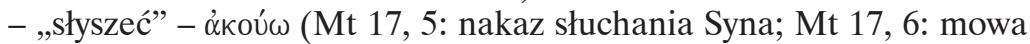
o usłyszeniu przez uczniów głosu; Dz 22, 7: Paweł słyszy głos; Dz 22, 9: towarzysze Pawła nie słyszą głosu);

- „Pan” - кúpıos (Mt 17, 4; Dz 22, 8 i 10);

${ }^{10}$ Dodatkowo w Mt 17, 3 występuje $\sigma \nu \lambda \lambda \alpha \lambda \lambda^{\prime} \omega$ (Mojżesz i Eliasz rozmawiają z Jezusem). 
- „Światło” - $\phi \omega \hat{~}$ (Mt 17, 2; Dz 22, 6. 9. 11);

- „rozmawiać” - $\lambda \alpha \lambda^{\prime} \epsilon \omega$ (Mt 17, 5: gdy Piotr mówił, osłonił ich obłok świetlany ${ }^{11}$; Dz 22, 9: towarzysze Pawła nie słyszą głosu mówiącego do niego; Dz 22, 10: w mieście powiedzą Pawłowi, co ma czynić);

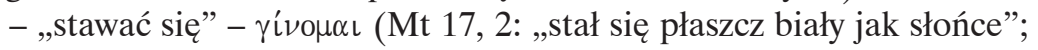
Dz 22, 6: „stało się, gdy się zbliżałem”);

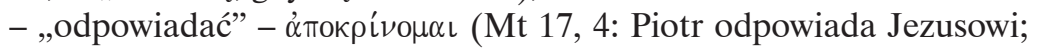
Dz 22, 8: Paweł odpowiada głosowi);

- „widzieć” - ópó $\omega$ (Mt 17, 3: dotyczy widzenia Mojżesza i Eliasza; Mt 17, 8: dotyczy widzenia ziemskiego Jezusa). W Dz 22, 9 występuje termin $\theta \in \alpha ́ o \mu \alpha \iota$ odnoszący się do towarzyszy Pawła, którzy widzieli światło, a w Dz 22, 11 - $\epsilon \mu \beta \lambda \lambda^{\prime} \pi \omega$ dotyczący braku widzenia przez Pawła. Termin ó $\alpha \dot{\alpha} \omega$ pojawił się też w Dz później, gdy Ananiasz przemawiał do Pawła, informując go, dlaczego został powołany $(22,14.18)$.

- ,jasność” (Mt 17, 2: „twarz Jego zajaśniała jak słońce, odzienie zaś

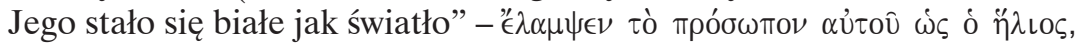

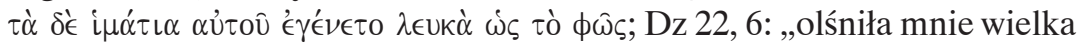

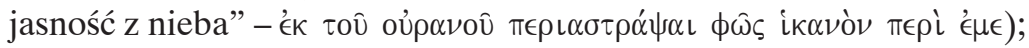

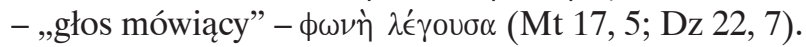

Podobieństwo terminologiczne należy ocenić jako bardzo duże. Wspólne terminy wydają się być istotne dla obu wydarzeń. Brak wspólnego terminu dotyczącego widzenia.

MT 17, 1-8 I DZ 26, 12-18

Wspólne ważne terminy i pojęcia to:

- „Jezus” - 'Iпбoûs (Mt 17, 1. 4. 7. 8. 9; Dz 26, 15);

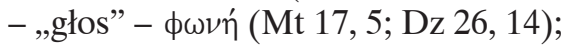

- „mówić” - $\lambda^{\prime} \epsilon \omega$ (Mt 17, 4: Piotr mówi do Jezusa; Mt 17, 5: głos z obłoku mówi do apostołów; Mt 17, 7: ziemski Jezus mówi do apostołów; Dz 26, 14: głos mówi do Pawła; Dz 26, 15: Paweł mówi do uwielbionego Jezusa, uwielbiony Jezus mówi do Pawła);

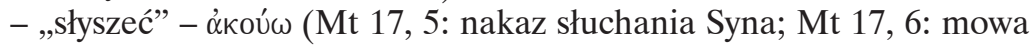
o usłyszeniu przez uczniów głosu; Dz 26, 14: Paweł słyszy głos);

- „Pan” - кúpıos (Mt 17, 4; Dz 26, 15 dwa razy);

- „Światło” - $\phi \omega \hat{~}($ Mt 17, 2; Dz 26, 13. 18);

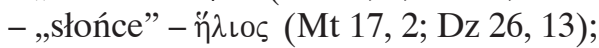

- „oczy” - ỏф $\theta \alpha \lambda \mu$ ós (Mt 17, 8: dotyczy oczu apostołów; Dz 26, 18 : dotyczy oczu pogan);

${ }^{11} \mathrm{~W}$ Mt 17, 3 użyte jest $\sigma u \lambda \lambda \alpha \lambda \epsilon^{\prime} \omega$. 
- „widzieć” - ópów (Mt 17, 3: dotyczy widzenia Mojżesza i Eliasza; Mt 17, 8: dotyczy widzenia ziemskiego Jezusa; Dz 26, 13: Paweł ujrzał jasność z nieba; Dz 26, 16: dwa razy dotyczy widzenia uwielbionego Jezusa, raz przyszłego objawienia Pawłowi przez uwielbionego Jezusa czegoś nowego);

- ,jasność” (Mt 17, 2: „twarz Jego zajaśniała jak słońce, odzienie zaś

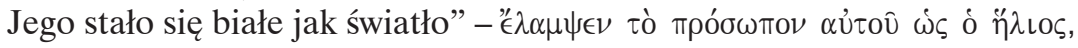

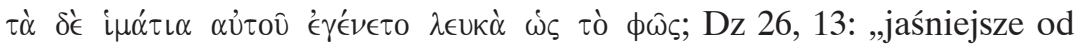
słońca światło z nieba, które oświeciło mnie zewsząd" - oủ $\alpha \nu$ ó $\theta \in \nu$ u̇tí $\rho$

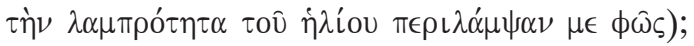

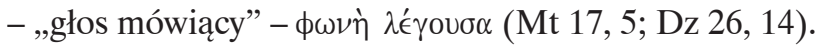

Podobieństwo terminologiczne należy ocenić jako bardzo duże. Wspólne terminy wydają się być istotne dla obu wydarzeń. Jest wspólny termin dotyczący widzenia, ale nie za każdym razem dotyczy widzenia uwielbionego Jezusa.

ŁK 9, 28-37A I DZ 9, 3-9

Wspólne ważne terminy i pojęcia to:

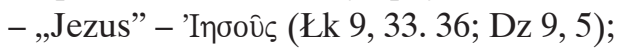

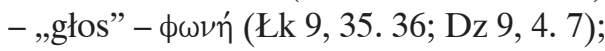

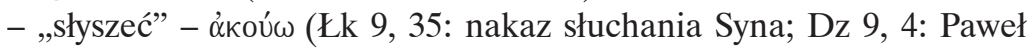
słyszy głos; Dz 9, 7: ludzie słyszą głos);

- „mówić” - $\lambda^{\prime} \gamma_{\omega}($ (Łk 9, 31: Mojżesz i Eliasz mówią z Jezusem; Łk 9, 33: Piotr mówi do Jezusa, Piotr nie wie, co mówi; Łk 9, 34: Piotr mówi; Łk 9, 35: głos mówi do apostołów; Dz 9, 4: głos mówi do Pawła; Dz 9, 5: Paweł mówi do Jezusa);

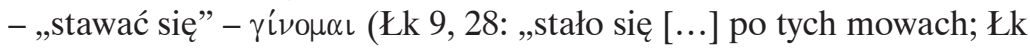
9, 29: „stało się, gdy się modlił; Łk 9, 33: „stało się, gdy odchodzili Mojżesz i Eliasz; Łk 9, 34: „stał się obłok”; Łk 9, 35: „stał się głos”; Łk 9, 36: „stał się głos”; Dz 9, 37a: „stało się, gdy następnego dnia”; Dz 9, 3: „stało się, gdy się zbliżał");

- „widzieć” - óó́w (Łk 9, 31: dotyczy widzenia Mojżesza i Eliasza; Łk 9, 32: dotyczy widzenia przemienionego Jezusa oraz Mojżesza i Eliasza; Łk 9, 36: „dotyczy widzenia - domyślnie - przemienionego Jezusa oraz Mojżesza i Eliasza. W Dz 9, 7 występuje termin $\theta \epsilon \omega \rho \epsilon \epsilon \omega$ i dotyczy braku widzenia kogokolwiek przez towarzyszy Pawła, a w Dz 9, 8. $9-\beta \lambda \epsilon ́ \pi \omega$ (dotyczy braku widzenia przez Pawła). Termin ó $\alpha \dot{\alpha} \omega \mathrm{w}$ Dz pojawił się też później, gdy Paweł w widzeniu ujżał Ananiasza $(9,12)$, oraz gdy Ananiasz powiedział Pawłowi, że Jezus, którego on widzi, przysłał go do niego $(9,17)$, 


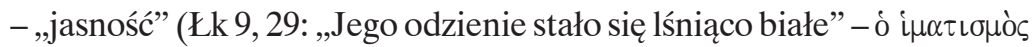

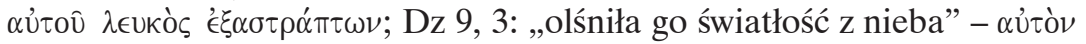

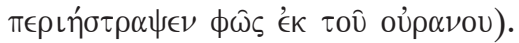

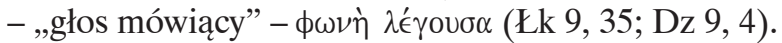

Podobieństwo terminologiczne należy ocenić jako duże. Wspólne terminy wydają się być istotne dla obu wydarzeń. Brak wspólnego terminu dotyczącego widzenia.

ŁK 9, 28-37A I DZ 22, 6-11

Wspólne ważne terminy i pojęcia to:

- „Jezus” - 'İбoûs (Łk 9, 33. 36; Dz 22, 8);

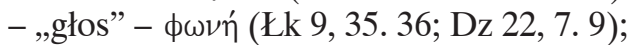

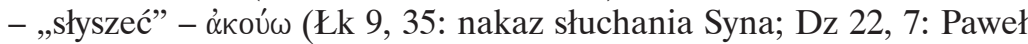
słyszy głos; Dz 22, 9: towarzysze Pawła nie słyszą głosu);

- „mówić” - $\lambda \dot{\epsilon} \gamma \omega$ (Łk 9, 31: Mojżesz i Eliasz mówią z Jezusem; Łk 9, 33: Piotr mówi do Jezusa, Piotr nie wie, co mówi; Łk 9, 34: Piotr mówi; Łk 9, 35: głos mówi do apostołów; Dz 22, 7: głos mówi do Pawła; Dz 22, 8: Jezus mówi do Pawła; Dz 22, 10: Paweł mówi do Jezusa, Jezus mówi do Pawła);

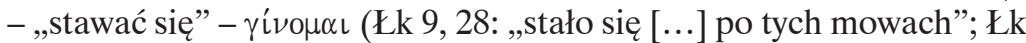
9, 29: „stało się, gdy się modlił; Łk 9, 33: „stało się, gdy odchodzili Mojżesz i Eliasz”; Łk 9, 34: „stał się obłok”; Łk 9, 35: „stał się głos”; Łk 9, 36: „stał się głos”; Łk 9, 37a: „stało się, gdy następnego dnia”; Dz 22, 6: „stało się, gdy się zbliżałem");

- „widzieć” - ópów (Łk 9, 31: dotyczy widzenia Mojżesza i Eliasza; Łk 9, 32: dotyczy widzenia przemienionego Jezusa oraz Mojżesza i Eliasza; Łk 9, 36: dotyczy widzenia - domyślnie - przemienionego Jezusa oraz

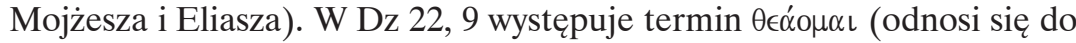
towarzyszy Pawła, którzy widzieli światło), a w Dz 22, 11 - $\epsilon \mu \beta \lambda \epsilon ́ \pi \omega$ (odnosi się do braku widzenia przez Pawła). Termin ópów pojawił się też w Dz później, gdy Ananiasz przemawiał do Pawła, informując go, dlaczego został powołany $(22,14.18)$;

- „rozmawiać” - $\sigma u \lambda \lambda \alpha \lambda \lambda^{\prime} \omega$ (Łk 9, 30: Mojżesz i Eliasz rozmawiają z Jezusem). W Dz 9, 6 jest $\lambda \alpha \lambda \lambda^{\prime} \omega$ : Paweł dowie się w mieście, co ma czynić;

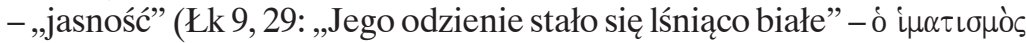

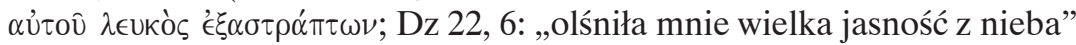

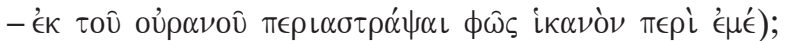

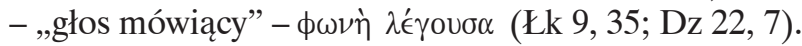

Podobieństwo terminologiczne należy ocenić jako duże. Wspólne terminy wydają się być istotne dla obu wydarzeń. Brak wspólnego terminu dotyczącego widzenia. 
ŁK 9, 28-37A I DZ 26, 12-18

Wspólne ważne terminy i pojęcia to:

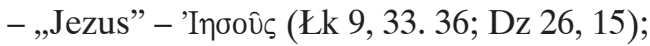

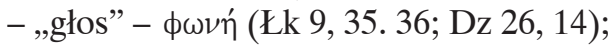

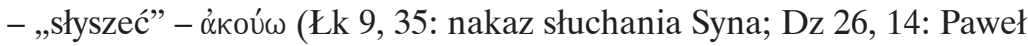
słyszy głos);

- „mówić” - $\lambda \dot{\epsilon} \gamma \omega(Ł k$ 9, 31: Mojżesz i Eliasz mówią z Jezusem; Łk 9, 33: Piotr mówi do Jezusa, Piotr nie wie, co mówi; Łk 9, 34: Piotr mówi; Łk 9, 35: głos mówi do apostołów; Dz 26, 14: głos mówi do Pawła; Dz 26, 15 : Paweł mówi do uwielbionego Jezusa; uwielbiony Jezus mówi do Pawła);

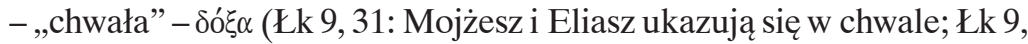
32: Piotr i towarzysze widzą chwałę Jezusa; Dz 22, 11: Paweł zaniewidział od chwały światła);

- „widzieć” - ópów (Łk 9, 31: dotyczy widzenia Mojżesza i Eliasza; Łk 9, 32: dotyczy widzenia przemienionego Jezusa oraz Mojżesza i Eliasza; Łk 9, 36: dotyczy widzenia - domyślnie - przemienionego Jezusa oraz Mojżesza i Eliasza; Dz 26, 13: Paweł ujrzał jasność z nieba; Dz 26, 16: dwa razy dotyczy widzenia uwielbionego Jezusa, raz przyszłego objawienia Pawłowi przez uwielbionego Jezusa czegoś nowego);

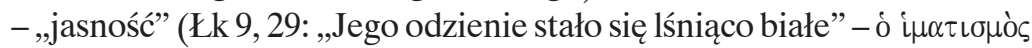

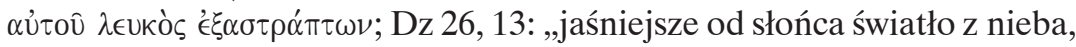

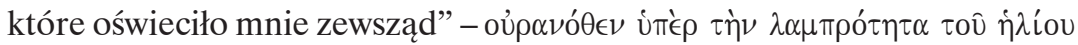
$\left.\pi \epsilon \rho \iota \lambda \alpha^{\prime} \mu \psi \alpha \nu \mu \epsilon \phi \hat{\omega} \varsigma\right)$;

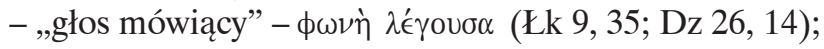

Podobieństwo terminologiczne należy ocenić jako duże. Wspólne terminy wydają się być istotne dla obu wydarzeń.

Powyższe porównania wskazują, że we wszystkich parach opowiadań

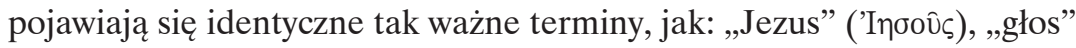
( $\phi \nu \nu \eta)$, „słuchać” ( $\dot{\alpha} \kappa o u ́ \omega)$ oraz „mówič” $(\lambda \dot{\epsilon} \gamma \omega)$, a ponadto wspólnym pojęciem, choć wyrażanym za pomocą różnych terminów, jest „widzieć”. Pojawia się także wspólna idea, choć wyrażona różnymi terminami, dotycząca spotkań z przemienionym i uwielbionym Jezusem.

Niektóre teksty dotyczące spotkania z przemienionym Jezusem i spotkania z uwielbionym Jezusem wykazują jeszcze dalej idące podobieństwa. Przede wszystkim należy zwrócić uwagę na różne modyfikacje zwrotu „głos

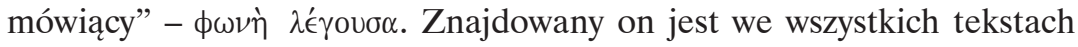
z wyjątkiem Mk 9, 2-8. 
Tekstami najbardziej zbliżonymi do siebie są: Mt 17, 1-8 i Dz 9, 3-9; 22, 6-11; 26, 12-18. W każdej parze posiadają one aż 8 wspólnych terminów, jeden pokrewny termin (dotyczący widzenia ${ }^{12}$ ), jedną wspólną ideę (dotyczącą światłości) oraz zwrot „głos mówiący”. Następnie należy zwrócić uwagę na pewien paralelizm tekstów pomiędzy Ewangelią św. Łukasza i Dziejami Apostolskimi: w poszczególnych parach pojawia się 5 wspólnych terminów, jeden pokrewny termin (dotyczący widzenia ${ }^{13}$ ), jedna wspólna idea (dotycząca światłości) oraz zwrot „głos mówiący”. Na nieco niższym poziomie należy widzieć paralelizm tekstów pomiędzy Ewangelią św. Marka i Dziejami Apostolskimi. Marek w porównaniu Dziejami, w poszczególnych parach, posiada 5 identycznych terminów oraz jedną wspólną ideę (dotycząca światłości), brak jest natomiast u niego ważnego zwrotu „głos mówiący”.

Pewien niedosyt może pozostawiać mniejsza rola widzenia przemienionego lub uwielbionego Jezusa we wszystkich analizowanych parach tekstów. Dzieje się tak, ponieważ tak jak w Starym Testamencie nacisk położony jest przede wszystkim na słuchanie.

\section{Podsumowanie}

Przeprowadzone analizy pozwalają wyciągnąc interesujące wnioski. Już ogólne porównania pomiędzy perykopami zawartymi w Ewangeliach synoptycznych oraz w Dziejach Apostolskich wskazują na pewne pokrewieństwo opowiadań o spotkaniu św. Piotra i pozostałych apostołów z przemienionym Jezusem oraz opowiadań o spotkaniu św. Pawła i towarzyszy z uwielbionym Jezusem. Paralele dotyczą postaci głównych bohaterów opisywanych wydarzeń, jak i ich przebiegu.

Szczegółowe analizy dotyczące terminologii nie tylko potwierdzają ten wniosek, lecz uzupełniają go o dodatkowe szczegóły. W niektórych zestawieniach istnieje dość daleko idące podobieństwo terminologiczne pomiędzy poszczególnymi perykopami opisującymi przemienienie Jezusa i spotkanie św. Pawła z uwielbionym Jezusem. Przede wszystkim dotyczy ono Ewangelii św. Mateusza i Dziejów Apostolskich.

Zauważone paralele pozwalają wyciągnąć wniosek, że wszystkie teksty dotyczące obu wydarzeń zostały w pewien sposób ze sobą zharmonizowane, choć stopień ich harmonizacji jest różny. Celem takiego zabiegu było zapewne ukazanie wiarygodności osoby św. Pawła w zestawieniu z osobą

${ }^{12}$ Termin ópó $\omega$ użyty jest zarówno w Mt 17, 1-8 jak i Dz 26, 18-12, jednak w różnym znaczeniu.

${ }^{13}$ W przypadku Łk 9, 28a-37a i Dz 26, 12-18 pojęcie dotyczące widzenia jest wyrażone identycznym terminem ó $\alpha \dot{\alpha} \omega$. 
św. Piotra. W ten sposób zyskał on legitymizację godności apostolskiej, ponieważ tak jak Piotr (i inni apostołowie) widział przemienionego Jezusa.

Powyższy wniosek zachęca do pogłębienia tej problematyki w oparciu nie tylko o analizowane teksty Ewangelii synoptycznych i Dziejów Apostolskich, ale i stosowne fragmenty listów św. Pawła. Jednocześnie przeprowadzone analizy mobilizują do postawienia następujących pytań: W jaki sposób mogło dojść do ewentualnej harmonizacji tekstów? Czy autorzy poszczególnych tekstów zarówno synoptycznych, jak i zawartych w Dziejach Apostolskich korzystali ze wspólnego źródła (wspólnych źródeł)? Dlaczego teksty zawarte u św. Mateusza i w Dziejach Apostolskich są sobie najbliższe? Dlaczego św. Łukasz w omawianym fragmencie nie jest najbliższy Dziejom Apostolskim, skoro według powszechnej opinii jest on autorem zarówno jednej jak i drugiej księgi? Wyciągnięty wniosek jak i postawione pytania, mogą stanowić podstawę do rozwijania zaprezentowanego tematu na gruncie zarówno teologicznym, jak i historycznokrytycznym w kolejnych artykułach.

Rzeszów

KS. MAREK DZIK

\section{Słowa kluczowe}

Jezus, Pan, Piotr, Paweł Apostoł, światło, głos, słuchać, mówić, widzieć, przemienienie, uwielbienie

\section{Summary}

The meeting of St. Paul with the transfigured Jesus at Damascus and the the transfiguration of Jesus upon a mountain

The article describes a possible connection between the transfiguration of Jesus and the meeting of St. Paul with the glorified Jesus at Damascus.

The article is divided into two parts. In the first part the author tries to find the main common elements between the two stories. He accounts for them: three versions of each story, the main characters of each story and the similar courses of each story. In the second part the author compares the terminology of each Gospel pericope with the terminology of each Acts pericope. He states that in each pair there are very important identical words such

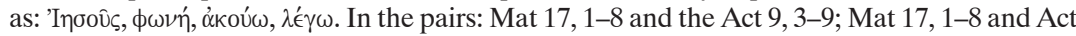
22, 6-11; Mat 17, 1-8 Act 26, 12-18 even more identical and important words can be found.

It allows the author to come to the conclusion that the story about the transfiguration of Jesus and the meeting of St. Paul with the glorified Jesus at Damascus are harmonized. It is probably done to prove that St. Paul is an apostle because he saw the transfigured (glorified) Jesus as did St. Peter (and the other apostles).

\section{Keywords}

Jesus, Lord, Peter, Paul Apostle, light, voice, to listen, to say, to see, transfiguration, glorification 
